\title{
THE POSITION OF NOTARIAL DEED IN THE SHARIA ECONOMIC DISPUTE
}

\author{
Yulies Tiena Masriani* \\ Department of Private Law, \\ Faculty of Law of Universitas 17 Agustus 1945, Semarang \\ Jalan Pawiyatan Luhur Bendan Duwur, Semarang, Jawa Tengah 50233
}

\section{Abstract}

Today the Indonesian economic system recognizes and applies the principles of Sharia into the National Legal System. Those principles are based on the value of justice, mutuality, equality, benefit and universalism (rahmatan lil 'alamin), particular in agreement (Akad). An Akad is laid down into an notary deed, the the parties are deemed to have agreed its contents and consequences. If one of the parties does not perform his obligation, there can emerge a dispute in the implementation of Sharia economic transactions. Therefore, the position of a notary deed is very important as an evidence in the dispute settlement.

Keywords: principles of Sharia, notary deed.

\section{Intisari}

Saat ini sistem ekonomi Indonesia mengakui dan menerapkan prinsip-prinsipnya Syariah ke dalam Sistem Hukum Nasional. Prinsip Syariah berlandaskan pada nilai nilai keadilan, kebersamaan, pemerataan, kemanfaatan dan keuniversalan (rahmatan lil 'alamin) khususnya Akad. Akad dituangkan dalam suatu akta notariil, maka para pihak dianggap telah menyetujui semua isi Akad dan konsekuensinya. Para pihak harus melaksanakan hak dan kewajibannya sesuai dengan isi akta tersebut. Apabila salah satu pihak tidak melaksanakan Akad tersebut, maka menimbulkan terjadinya sengketa dalam pelaksanaan transaksi ekonomi syariah. Oleh sebab itu, kedudukan akta notariil sangat penting sebagai alat bukti dalam penyelesain sengketa tersebut.

Kata Kunci: prinsip-prinsip syariah, akta notaris.

\section{Pokok Muatan}

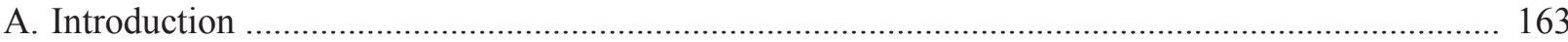

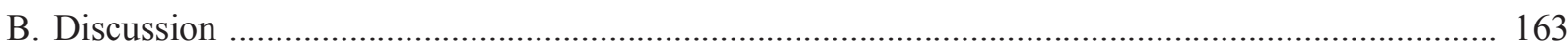

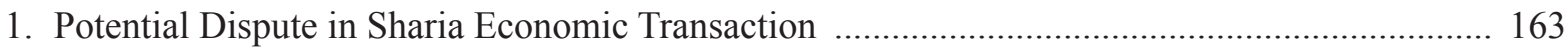

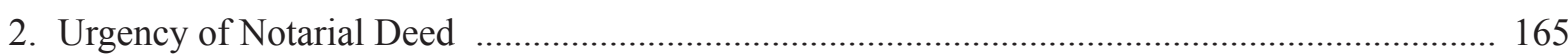

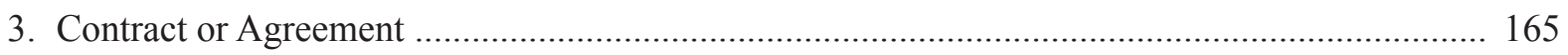

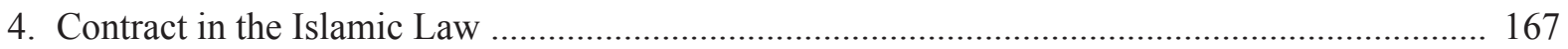

5. Urgency of Notarial Deed in Sharia Economic Transaction .................................................... 169

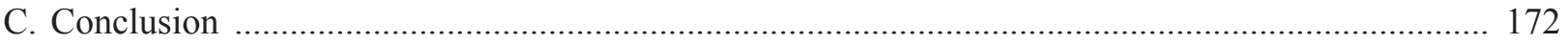




\section{A. Introduction}

One of national development goals (NDG) is the creation of justice and prosperous society based on the economic democracy in developing the economic system underlied on the fair market mechanism. To achieve and also to involve the goals in a healthy global competition actively, there must be participation and constribution of all elements of the society in digging various existed potentials to espouse the economic acceleration process. One of the potential aspects is the economic system of developing development in the Islamic value (Sharia) with implemeting its principles into the National Legal System. Those principles are based on values of justice, mutuality, equality, benefit and universalism (rahmatan lil 'alamin). ${ }^{1}$

Today, Sharia Financial Institutions (SFI) have grown rapidly in Indonesia. It prompts people to know what the basic distinction is between the Sharia and Conventional Financial Institutions. Obviously, the SFI should have a very clear transaction, that is money should not be profitable on its own without any transaction such as buying and selling causing margin, lease causing fee, and capital investment earning profit sharing. In other words, the basic distiction is based on agreements (Akad) and transactions. ${ }^{2}$

Akad is a parameter that causes a transaction valid or invalid. The transaction by an Akad should be laid down in a notarial deed in accordance with the principles of Sharia, and the parties then considered to have agreed and known all the contents of the contract in thereto. Consequently, they should respect their Akad.

The problem will occur when one of the parties who made and agreed the Akad does not respect and perform it. It can give rise to a dispute between the parties in the implementing of Sharia economic transaction. This article discusses the position of a notary deed in the evidentiary dispute of it.

\section{B. Discussion}

\section{Potential Dispute in Sharia Economic Transaction}

One of the Sharia economic transaction is the financial banking that is Sharia bank. Such bank is not very different with the conventional bank in its function as a intermediary institution which aims to collect funds from the public and distribute them back to those who need financing. The financing is the providing of funds or collection compatible to it given by a party in this respect sharia bank to another party in the planned investment. According to Article 2 Act on SB, Sharia (Islamic) banking in conducting business based on the Sharia Principle, economic democracy, and prudential principles as well as using bank management guidelines that must be adhered to realize the healthy, strong, and efficient banking system under applicable laws. ${ }^{3}$

The operated banks in Indonesia Generally consists mainly of two types among others conventional bank dan Sharia bank. Their essential distinction is underlied on the transaction using the interest system. The conventional bank applies the high interest; otherwise the Sharia bank prioritizes the system of sharing profit taking into account the conditions of society and the Islamic law.

The principles of Sharia banking must be met, inter alia: a) Prinsip at-Ta'awun reflects a mutual assistance); b) The principle of avoiding al-Iktinaz is a principle that emphasizes the use of money such as do not leave the money idle but make it in the effective transaction to the public.

\footnotetext{
Elucidation of Act No. 21 of 2008 on Sharia (Islamic) Banking (abbreviated as Act on SB) (State Gazette of the Republic of Indonesia Year 2008 Number 94, Supplement to State Gazette of the Republic of Indonesia Number 4867).

Fathurrahman Djamil, 2012, Penerapan Hukum Perjanjian dalam Transaksi di Lembaga Keuangan Syariah, Sinar Grafika, Jakarta, p. v.

Trisadini Prasatinah Usanti, Urgensi Jaminan pada Pembiayaan Berdasarkan Prinsip Bagi Hasil di Bank Syariah in M.Isnaeni, 2013, Perkembangan Hukum Perdata di Indonesia, Laksbang Grafika, Surabaya, p. 235. See Elucidation of Article 2 of SB is prescribed that "Economic democracy" is defined as a sharia economic activity that contain fairness, mutualness, equality, and benefit. "Prudential principle" is defined as bank management guidance that must be complied to create a sound banking, strong, and efficient according to the provisions of prevailing laws and regulations.
} 
This is in accordance with the Surah an-Nisa verse $29 ;{ }^{4}$ c) strictly forbidden to carry out a transaction if there are such things as follows: Gharar, there is an element of uncertainty or fraud in a transaction. Maysir, there is an element of gambling having the quality of speculative transactions which can result in losses of a parties and in benefit for another one. And Riba or usury is a transaction armed with the interest system. ${ }^{5}$ The potential conflict in practice of sharia economy, especially sharia banking that is a dispute between bank and client be in the form of complain because of a discrepancy between reality and bid, any inconsistency to the approved rules, services and bureaucracis that are not included in the contract, and also complaints against the slow process of working. The important thing performed by the parties in a dispute settlement of Sharia economy is a deliberation to reach consensus in the implementation of the agreed contract. Furthermore, if it is not successful, there are many ways conducted by institutions such as banking mediation, arbitration institution, a court in the Religious Court circle and a court in the Commercial Court circle as long as it is agreed upon in the Akad by the parties.

Basically, the methode of dispute settlement depends on the parties entirely. It can surely be said that the principle of pacta sunt servanda and freedom of contract as stipulated in Article 1338 jo 1320 of Kitab Undang-Undang Hukum Perdata or the Indonesian Civil Code (abbreviated as ICC). ${ }^{6}$ Article 55 paragraph (2) Act on SB states that there are authorized parties settle disputes in connection with the contents of contract, among others: a) a deliberation; b) banking mediation; c) Sharia National Board of Arbitration (Badan Arbitrase Syariah Nasional/Basyarnas) or other boards of arbitration; and/or d) a court in the jurisdiction of public judiciary i.e. Religious Court. Alternative Dispute Resolution (ADR) of sharia economy in Religious Court is based on Act No. 3 of 2006 on Amendment of Act No. 7 of 1999 on Religious Judicary.

There are some cases in which could be handled by the Religious Court such default in contract or breach of contract because one of the parties did not performed the approved contract, for instance, a dispute between Retired Funds or Dana Pensiun Angkasa Pura II (Dapenda) and PT Bank Syariah Mandiri. The dispute began from the verdict of Basyarnas in August 2008 in which declared that Bank Syariah Mandiri and PT Sari Indo Prima should pay primary financing in Mudharabah Muqayyadah Akad to Dana Pensiun Angkasa Pura II (Dapenda) in the amount of 10 billion IDR. That verdict was not fulfilled, ultimately Dapenda pleaded execution of confiscation to the Central Jakarta Religious Court. Other cases, such as Bank Mega Syariah case concerning gold pawn, Pertamina case v. two sharia banks concerning al-murabahah (buy and sell) financing and fictitious credit where in Akad making the debtor did not attended and there was a copy of certicate as a collateral.

The above cases are resoluted by way of nonlitigation beforehand. If such settlement does not work successfully, the parties then will be settled through litigation in the Religious Court. The main principle must be really understood and noted in the settlement of Sharia banking cases particularly and Sharia economic cases generally that the process of dispute settlement absolutely should not be contrary to the principles of Sharia. This is the most important thing to perform the cases by the Religious Court as

\footnotetext{
Surah an-Nisa verse 29: "O ye who believe! Squander not your wealth among yourselves in vanity, except it be a trade by mutual consent, and kill not one another. Lo! Allah is Merciful unto you”, See Marmaduke Pickthall, 1938, The Meaning of Glorius Koran, Government Central Press, Hyderabad-Deccan, p. 82.

Mardani, 2014, Hukum Bisnis Syariah, Kencana Prenata Media Group, Jakarta, p. 155. See Elucidation of Article 2 states that usury is illegally obtain additional income ( $b a t i l$ ) among others the exchange transaction of similar types of goods but of different quality, quantity, and delivery time $(f a d h l)$, or in lending transaction requiring the Facility Receiving Customer to repay the fund received exceeding the principal due to the passing of time (nasi'ah); maisir is a transaction depending on unstable condition and on luck; gharar is a transaction of which is the object is not clear, not own, not known its whereabouts, or cannot be delivered at the time of transaction unless otherwise regulated in sharia; haram is a transaction of which the object is prohibited in sharia; or zalim is an unfair transaction for the other party.

6 Frans Hendra Winata, 2011, Hukum Penyelesaian Sengketa Arbitrase Nasional \& Internasional, Sinar Grafika, Jakarta, p. 31.
} 
stipulated in Article 55 paragraph (3) of Act on SB.

The Sharia economic transaction has a potential dispute if the Sharia bank does not perform successfully in accordance with the principles of the Islamic banking. It, however, was noted in bookkeeping but the bank merely violated the prudential principle because the system has not been perfect.

The transaction should meet the fatwa that is a legal opinion or learned interpretation or decree handed down by an Islamic religious leader or ulema, of National Sharia Board of Indonesian Ulema Council (DSN-MUI) or Dewan Syariah Nasional - Majelis Ulama Indonesia (DSNMUI). The fatwa is the stated in a Bank Indonesia Regulation. ${ }^{7}$ However it is considered into to Sharia or not. It ultimately may induce potential conflicts or disputes. Therefore the parties should fulfill what has been stipulated in their contract with good faith based on the principles of Sharia.

\section{Urgency of Notarial Deed}

A deed is a written instrument which has purposely been made to be a proof of an event and signed by those who make it. A notarial deed is a deed, before it is signed before a notary, which must be read to the parties by the notary or by a third person appointed by him. Its contents are considered as the will of the parties but the notary as a public official must not fully take responsibility for them with regard to provisions therein. He also shall have and keep in a proper state of a repertory of the date and the name of the parties.

According to Article 1 point 7 of Act No. 2 of 2014 on Amendment of Act No. 30 Year 2004 on The Office of Notary (Notary Act), Notary Deed is an authentic deed made by or before a notary in accordance with to the forms and procedures stipulated in this Law. In General Elucidation of Notary Law stated that Notary deed virtually contains the formal truth according to what the parties notify the Notary.
Pursuant to Article 1867 of ICC that an deed shall be made by writing under the hand or in authentic writing. A writing under the hand (onderhandsche geschriften), according to Article 1874 of ICC, is a deed shall be considered to be, all privately signed deeds, letters, registers, documents pertaining to household matters and other documents, which are drawn up without the intervention of a public official. Article 1875 states that if this deed which has been acknowledged by the individual to whom it may refer or which shall be considered legally acknowledged, is provide, with respect to the signatories and their heirs and parties having rights therein, conclusive evidence similar to an authentic deed.

Articles 1868 constitutes an authentic writing or deed (authentieke acte) is a deed which has been drawn up in a legal format, by or before public officials who are authorized to do so at the location where this takes place. One of the public officials refers to notary. This deed should comply term of condition, inter alia: 1) it shall be made or before a public official; 2) it shall be made in the form as prescribed by the law; and c) it shall be made by a public official or before one who has the authority to make it.

The notarial deed is also classified as an authentic deed. It has a perfect and powerful evidence so that it can give the legal certainty and escape any dispute between the parties. Setting out an act, agreement and decision in a notarial deed could be better than in writing under the hand, even though signed on stamp duty as well as by witnesses.

The Sharia economic transaction knows also a notarial deed be in the form of Akad. An agreed Akad is an agreement of a legal act which has been taken by the parties to gain the legal certainty.

\section{Contract or Agreement}

A contract or an agreement is any understanding or arrangement reached between two or more parties must be in accordance with the the 
principles of existing contract. It is based not only on Western contract law and but also on Islamic contract law with respect to the Indonesian context. The definition of contract derives from the Wester private law. According to Agus Yudha Hernoko, the dynamic development in the current contract law is coloured by a thin veil of separator between two mainstreams of the legal system i.e. common law and civil law, particular in commercial contracts in which connect business actors transcend national boundaries. Departure from this event gives what kind of a significant effect by adoption of the universal principles developed in the customary practice trade law (lex mercatoria). ${ }^{8}$

Notwithstanding the paradigm change of the contract law has daily been occured, especially notarial deeds which are always based on the principles of general agreement stipulated in ICC. The definition of contract is debatable in the circle of jurists whether is will be using the word "contract" or "agreement".

Referring to the ICC, particular in Book III: Chapter II concerning Obligations arising from contracts or agreements (Van verbintenissen die uit contract of overeenkomst geboren worden), the term of contract and agreement is similar vice versa. Some legal scholars still stand it up, among others: Jacob Hans Niewenhuis, Hofmann, J. Satrio, Soetojo Prawirohamidjojo dan Marthelana Pohan, Mariam Darus Badrulzaman, Purwahid Patrik, dan Tirtodiningrat. In addition, a different view expressed by Subekti who separated the term of "agreement or consent" and contract that the word "contract" has a narrower sense because of referring to agreement or writen agreement. ${ }^{9}$ According to me, Subekti's point of view is based on Article 1320 of ICC where an agreement or consent without any without any written form such as an contract is still valid. ${ }^{10}$ This article states clearly: "In order to be valid, an agreement must satisfy the following four conditions (tot bestaanbaarheid der overeenkomsten worden vier voorwaarden vereischt): 1) there must be consent of the individuals who are bound thereby; (de toestemming van degenen die zich verbinden); 2) there must be capacity to enter into an obligation; (de bekwaamheid om eene verbindtenis aan te gaan); 3) there must be a specific subject matter; (een bepaal onderwerp); and 4) there must be a permitted cause (eene geoorloofde oorzaak).

From the above provision be operated into firstly, "a term of agreements" shall means the law maker (wetgever) shows nominate and innominate agreements. This is set out in Article 1319 of ICC which specifies "All agreements, whether or not known under specific titles, shall be subject to the general provisions, which shall be the subject of this and the previous title". Furthermore, there is also a case of a high degree of autonomy party (er is hier sprake van een hoge mate van partijautonomie). Secondly, "a term of legally" shall mean the law maker (wetgever) points out an agreement making should satisfy the stipulated requirements and is binding as a law to the parties in realizing the legal certainty. Thirdly, "a term of good faith (ter goede trouw)" shall mean the law maker (wetgever) gives the legal protection to debtor and the legal standing between debtor and creditor is equal. This denotes the realization of the principle of equilibrium.

The freedom of making contract is one of the most important principles in the contract law. This freedom is an embodiment from the free will as an manifestation of human rights. In other words, if the parties make an agreement and they must pay attention to the provisions stipulated by the written and unwritten laws. Anticipating any default or breach of contract and providing the legal binding an agreement should be in writing in order that this agreement can be an evidence in the form of a notarial deed having a full proof (volledig bewijs).

\footnotetext{
Agus Yudha Hernoko, 2010, Hukum Perjanjian, Asas Proporsionalitas dalam Kontrak Komersial, Kencana Prenada Media Group, Jakarta, p. 9.

$9 \quad$ Ibid., p. 13. See also, Peter Mahmud Marzuki, 2011, An Introduction to Indonesian Law, Setara Press, Malang, p. 236.

10 Subekti, 1975, Pokok-Pokok dari Hukum Perdata, Intermasa, Jakarta, pp. 112-115.
} 


\section{Contract in the Islamic Law}

The principle of contract in the Islamic Law, in general, is like agreement or consent laid down in a deed. A contract in this law is known as Akad made by two parties arising the principle of consent of the individuals who are bound thereby. In other words has been started with offer and acceptance (Ijab-qabul) concerning a specific subject matter.

A contract or an agremeent in principle still refers to the norm which has been outlined by Article 1320 of ICC consists of consent (toestemming), capacity (bekwaamheid), a specific subject matter (een bepaal onderwerp) and a permitted cause (eene geoorloofde oorzaak). By compliance of those four conditions, an agreement will become valid and legally binding to the parties who make it. ${ }^{11}$ Tim Lindsey et al define a contract or an Akad is a mutual consensus or commitment in spoken, annunciation and writing between two parties or more which can lead to impact of legally binding consequences to be enforced by them. The point is that there must be a relationship between offer (ijab) and acceptance (kabul) underlying the Akad. ${ }^{12}$

In the lexical terms as quoted by Rahmani Timorita Yulianti, the word "Akad" derives from Arabic referring to relationship or affiliation not only visible relationship but also invisible relationship. ${ }^{13}$ The al-Mawrid Dictionary translates al-'Aqd as contract and agreement, whereas according to an expert on Islamic law, Subhi Mahmasaniy implis contract as pledge or relationship between $i j a b$ and qabul can lead to the legal consequnce towards the to contracted things. Another expert opinion clarifies Akad is an intentional act made by two parties based on mutual consent or compliance. ${ }^{14}$ Rahmani Timorita Yulianti underlines that a contract is a mutual consent or compliance in spoken, annunciation and writing between two parties or more which can lead to impact of legally binding consequences to be enforced by them. ${ }^{15}$

In Akad, the Islamic law always emphasizes the element of outward and inward. For instance, Iltizam shall generally means such Akad embedies a legal action (rechtshandeling) derived from the will of the parties. Moreover, there is also another example that is tasarruf or conduct or disposition with respest to everything that comes from the will of someone either word or deed, in which the terms set upon a number of legal consequences, concerning the interests of the person or others. This agreement can be in the form of buy and sell, grant, benefaction or on the contrary regarding an act as an acquisition of free property not having an owner, consuming and using the property according to Islamic Law. ${ }^{16}$

According to the ulemas, fulfilling an Akad shall be met, foremost, by its commandments (rukun) and requirements (syarat). The pillars show the presence and absence of an act; otherwise the requirements are part of the commandments but not the essence of the act. In consequence, they must be complied: ${ }^{17}$ First, ijab and qabul, these should be consistent and performed in a place and connected to one another. Second, mukallaf means capacity to enter into an obligation. The object of the Akad is real and exist, not only for the present but also for the future, permitted or lawful (halal), can be harmonized. The purposes of the Akad must be in accordance with the Islamic law means it may not be contrary to the rules of the Koran and the Hadith such as forbidden items. In other words, the principles of Islamic banking reflect and implement the principles of Islamic law issued by MUI as an body is authorized to stipulate the fatwas on a large

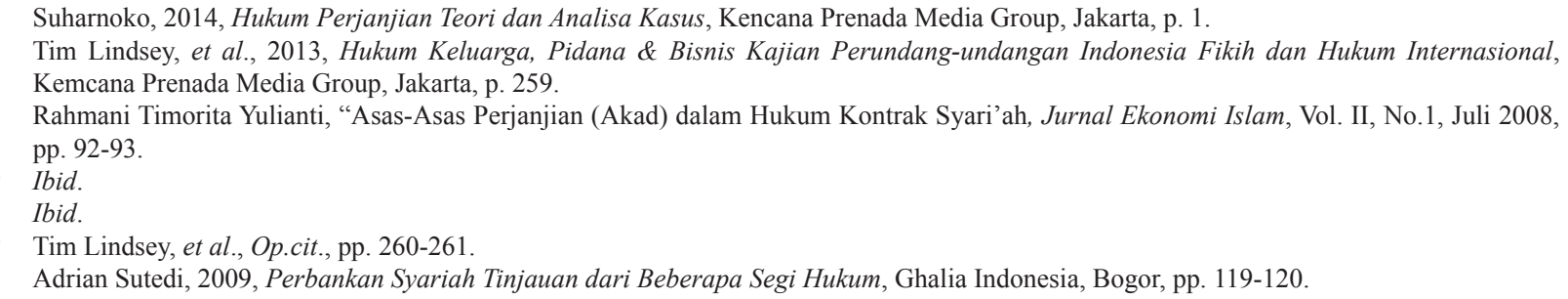


variety of Sharia in Indonesia.

It has aforesaid been propounded that the commandments of Akad in Sharia economic transactions referred to agreeement genarally. According to Ahmad Azhar Basyir, the transactions can be detailed fhe following: First, subject of the Akad that is the parties who make in a legal and binding document having capacity in the terms of age and mental ability to condut their legal act. Second, the object of the Akad should be in its form, for instance an Akad of sell and buy, the object is in the forms of bought and sold goods and prince. ${ }^{18}$ In order the Akad is legally enforceable, the object shall meet as follows: First, there must be exist at the time the Akad is created. A nonexistent object could not be the object of the Akad. Pursuant to the fukuha, law of the cause and effect depends on an object that has not been already exist. Second, there must be valuabe. For instance, an Akad of sell and buy, the object must be valuabe for the parties. Third, there must be determinable and knowable for the parties. The obscure object in an Akad can lead to a dispute at a later date so that it can be void. These conditions are necessary intend to the Akad conducted by the parties. In other words, they are agreed by the fukuha. Fourth, there must be handed over at the time the Akad is occurred. It shall means by the time specified in the contract that the object must be handed over because it is under the authority of a legitimate party.

From the various prepositions argued, we can indentify the Akad consists of the parties who are bound thereby in a specific subject matter. Furthermore, itshould be conducted by ijab and kabul and based on the Islamic law. ${ }^{19}$ It based on the Islamic Law should be respected and carried out by the parties by the role of Notary. In other words, its commandments and requirements of do not lead to any harm to the others.
The Akad does impose the obligation to the parties to fulfill it as prescribed in surah al-Maidah verse 1, Allah says: "O ye who believe! Fulfill your undertakings". Abd. Shomad points out that the fulfillment in the Akad represents the rights and obligations between human beings for the mutual benefits. $^{20}$

There are three main principles in the agreement in Islam asserted by Maha-Hanaan Balala contractual fairness, social justice, and permissibility. Contractual fairness shall mean Islam promotes the principle of equality of every human being without exception. This explicitly declares in surah al-Hujaraat verse 13, God says: "Indeed, the most noble of you in the sight of Allah is the most righteous of you". ${ }^{21}$ Bargaining position must then be fairness without exception. The social justice shall mean Islam builds every good deed committed by every human being should bring avails and benefits and also have no harmful for the life. This emphasizes a social responsibility which must be manifested in every Akad in realizing rights and obligations do not cause any harmful or loss for the others. The Permissibility shall mean that the Akad is not forbidden by the Koran and Hadith. These two guidances prescribe to the standard Akad which identifies as the ultimate source of law. ${ }^{22}$

Thus, the business world based on the Islamic law implementing the agreement in the form of Akad becomes a contractual basic undergoing the significant enhancing. The Islamic banking as a prime mover to the economic community makes use of the business based on Sharia in an Akad and involving the role of Notary in the making of it should really be performed in accordance with the two ultimate sources of Islamic law that are the Koran and Hadiths. In addition, this concept can bring justice to the people; otherwise, the Islamic banking is not just manifestation of the

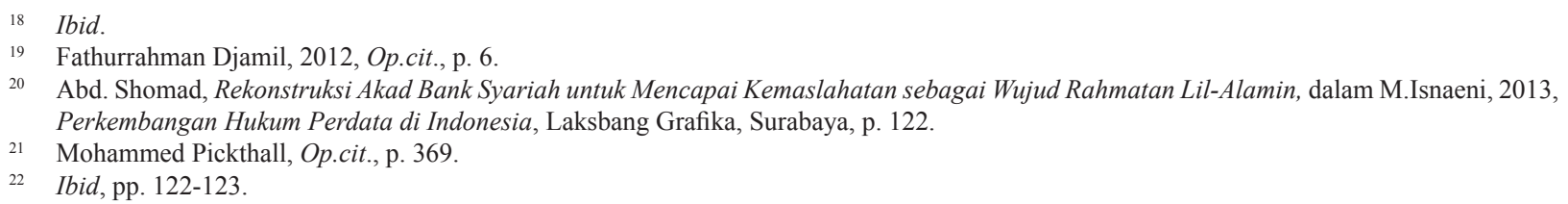


representative of the banking products seeking merely profits. ${ }^{23}$

\section{Urgency of Notarial Deed in Sharia Economic Transaction}

What is meant by the term of "urgency", according to W.J.S. Poerwadarminta, has two meanings that are something should immediately be done and something is urgent requiring immediate action. ${ }^{24}$ The urgency of notarial deed should be meant that the deed made before a notary having a very important standing and becoming an immediate measure which must be taken to secure the legality of a legal act. Sometimes it has been argued that in many pratices the urgency can happen in any situation related to temporary caused by any opportunity or chance. The urgency of notarial deed in Sharia economic transactions is purposed to making of it in which contains provisions or clauses providing a way of dispute settlement if one of the contracting parties does not comply what has been agreed in Akad.

A legal act taken by means of use of an agreement in the form of notarial deed in Sharia economic transactions should to Notary Act, fatwas, of National Sharia Board of Indonesian Ulema Council (DSN-MUI) or Dewan Syariah Nasional - Majelis Ulama Indonesia (DSN-MUI) and Indonesian Central Bank that is Bank Indoenesia.

In every notarial deed in the form of Akad in Sharia economic transactions provide a provision or clause regarding dispute settlement that states:

- In the event of any dispute, claim, question, or disagreement arising from or relating to the dissenting opinion in understanding or interpreting parts, or any alleged breach thereof in complying of this Akad, the parties hereto agree first to try in good faith to settle the dispute through negoitation;

- $\quad$ If the dispute can not be settled through negoitation as referred to in paragraph
1 of this Article, then the parties hereby agree to submit the following dispute to mediation and to refer to a lawful permanent resident (domicile) at the Registrar of the Religious Court of Semarang;

It can be a crucial point dan needed in every transaction to secure the legal certainty, utility and justice. It can also be reached by applying profitsharing system. A provision or clause of dispute settlement in an Akad should also be provided if there arises any dispute, contreversy, or disagreement out at a later date. According to Article 15 paragraph (1) of Notary Act states that a notary authorized to perform acts, agreements and stipulations which are governed by the laws and regulations and/or required by the respective party shall secure the certainty of date of the notarial deed, keep the deed, give a duplicate, copy, transcript of the deed. All performs in accordance with making of the deed shall be empowered to every notary unless to other officals or others stipulated by law.

Moreover, the Notary has also other authorities laid down in Article 15 paragraph (2) of Notary Act among others : a) certify the signature and lay down certainty under the date of the hand by enrolling in a special book; b) posted a letter under the hand by enrolling in a special book; c) make a copy of the original letter under the hand in the form of a copy of which contains a description as written and illustrated in the letter in question; d) approve the suitability of photocopies with the original letter; e) provide legal counseling in connection with the manufacture of the Deed; f) Deed relating to land; or g) Deed treatise auction.

The study towards the urgency of notarial deed in Sharia economic transaction associates a combination of two legal systems that are Western private law and Islam private law. Such phenomenon can not be separated from existence and recognition to the Sharia law in Indonesia that in fact Indonesia 
is the largest number of the population as Muslim, about 207 million or $87.2 \%$, however the country is not a Islamic state.

The principles of Islamic law promotes the principles of muamalah that is judgments that were related to the laws of commodities, loans and trade, in which the decrees of transactions. ${ }^{25}$ In particular these principles are classifies in two things according to Fatturahman Djamil, ${ }^{26}$ following: first, the forbidden things conducted in the activity of muamalah are object trading and business must be halal and good (thayyib) in accordance with the will or compliance (antaradhin) and trusted management. The concept of halal object determines its elements in the form of a business not forbidden by the Islamic law such as selling alcohol drink, excrement, gambling and so on. The preference is based on the norms of Islamic law that do not merely intend to the desire of profits. The other side, what is meant by the term compliance (antaradhin) is referring to surah an-Nisa verse 29 with the phrase "antaradhin minkum" shall mean it be a trade by mutual consent. This verse underlines that the trade should be based on mutual consent between the parties. In other words, there is no any principle of "coercion" in every transaction from any party. In addition, the financial management in business must have the value of honesty and trusful which reflect the character of Prophet and Messenger Muhammand SAW. Second is riba that is any additional loans derived from excess of the principal amount that must be given to creditors; takhir is object of trade but not in the hands or owned, unknown, can not be deliverd at time, resulting the loss for the debtor, regret and danger; tadlis is where goods have been obtained by fraud or damage.

The Sharia compliance in Sharia economic transactions currently becomes a public discourse or an attention of stakeholders of the Islamic banks towards the principles of Islamic law, that the banks do not comply those principles. Somehow the society notices the distuingishing of theory and practice. The view of justification that the business actors of Islamic financing must imply the prudential principle to keep the maintenance of the Sharia compliance aspect as a tool of preventive for the possible risks and frauds in the real sector. Futhermore, the need of financial inovative products and services must be done with the adaptability between profit, social dynamics and world economy or economic global. This is applied to proof that the Islamic values are able and exist in the competitive global economy in the modern time in general and also to maintain the sustainble business of Islamic banking in Indonesia in particular.

The complaince function creates measures and actions having ex-ante or preventive to ensure policies, regulations, systems, prosedures and business activities performed by the Islamic banks. With this regards, those banks have obligation to envisage all applicable regulations as result of the individual responsibility from the board of directors to the lowest ranking of employees. Moreover, the financial innovative products of the Islamic banking must be derive from the basic of the Sharia standards and governances, the international standards, the fulfillment of integrity, the quality of human resources, the suitability of Akad and do not oppress people as consumers. ${ }^{27}$

The discussion on the products of Islamic banking based on the Islamic Law can not be separated from the principles and utilities of the Sharia economy. The principles can be assumed as a pilar of it which can give utilites for the public welfare. They are the following principles: a) Be ready to accept the risk that every moslem have to work to survive him self and his family by accepting

\footnotetext{
25 Ahmed Akgunduz, 2010, Introduction to Islamic Law Islamic Law in Theory and Practice, Islamitische University Press (IUR), Rotterdam, p. 241.

Fathurrahman Djamil, 2013, Hukum Ekonomi Islam: Sejarah, Teori dan Konsep, Editor Tarmizi, Sinar Grafika, Jakarta, pp. 156-161.

27 Budi Sukardi, "Kepatuhan Syariah (Syariah Z Compliance) dan Inovasi Produk Bank Syariah di Indonesia", http://stainmetro.ac.id/e-journal/
} index.php/akademika/article/download/61/55, accessed on November 18, 2015. 
the risk in accordance with his work; b) do not hoarding shall mean the Sharia economy prohibits to hoard money or idle money; otherwise it should be utilized for economic activities; c) do not monopoly and oligopoly shall mean the Sharia economy does not instruct both individuals or business actors to implement the system of monopoly and oligopoly; and e) the prohibition of riba (usury or interest) in the form of compound interest. ${ }^{28}$

There are several utilities which can be obtained with the implemention of the Sharia economy, as follows: a) realizing the integrity of every moslem regard to the "total Islam" or kaffah. If a moslem is still werstled with the conventional economic containing the element of usury (riba). It can be said that he has not been kaffah because he does not obey the Islamic principles; b) implementing and practicing the Sharia economy through Islamic bankings, insurances, mutual Funds, pawns and/or Islamic CommunityBased Microfinance (Baitul Maal wat Tamwill BMT) to attain happiness both in the world and in the hereafter. The happiness in the world is the profit sharing and the happiness in the hereafter is unrestrained by the usury (riba). In addition, a moslem who has been implementing the Sharia economy get good deeds as the value of worship; c) the implementation of the Sharia economy means promoting the program of commanding the proper and forbidding the improper (amar ma'ruf nahi munkar), because the collected funds must merely deal with the permitted or lawful businesses based on the Koran and the Hadiths. The Islamic bankings do not intend to provide funds for the unpermitted or unlawful businesses (haram); and d) the object of Akad should be tangible, proprietary and also applied by the law. Thus the Akad based on the Islamic law must be respected and carried out by the parties involving the role of a notary as a neutral party. Thus, its conditions and requirements do not create the harms for the others.

Today, the world business of Sharia economy based on Akad as a contractual basic is emerging the significant development. The Islamic bankings as the primer mover of social economic are applying their business based on the Islamic law in an Akad and also cooperating with the notary in the deed making process. Moreover, such concept can realize justice for the people; otherwise, it is only manifestation as the representative of banking products seeking profits thereto. ${ }^{29}$

According to Habib Adjie, Article 1 point 13 of Notary Act declares that the Akad is a written covenant between a Sharia (Islamic) Bank or Sharia (Islamic) Business Unit and other parties containing the respective rights and obligations of the respective parties according to the Sharia Principle. This article is a mandatory rules. Furthermore, the content or substance of a written agreement must be containing the respective rights and obligations the respective parties in accordance with the Sharia Principle. Habib Adjie asserts that the practice of the Islamic Banking or Sharia Business Unit or Unit Usaha Sharia (USS), there must be a written consent laid down in a notarial deed or a deed under the hand. Consequently, the deed distinguish the deed of the Islamic bank or the conventional bank. The most prominent indicationf of the deed of the Islamic bank is beginning with the inclusion of a certain sentence that is "Bismillaahirramanirrahiim" means "In the name of Allah, the Beneficent and the Merciful". In addition, the sentence is followed by two surah that are surah Al-Baqarah verse $275^{30}$ and surah $A n$ Nisa verse 29 or merely mentioned with the phrase "Bismillaahirramanirrahiim" in the beginning and terminated with a sentence "Insya Allah semuanya mendapatkan berkah" or "If Allah will (Inshallah) everything gets the blessing" in the end. ${ }^{31}$

\footnotetext{
Zainuddin Ali, 2009, Hukum Ekonomi Syariah, Sinar Grafika, Jakarta, pp. 7-8.

Ibid.

Surah Al-Baqarah verse 275: "Those who swallow usury cannot rise up save as he ariseth whom the devil hath prostrated by (his) touch. That is because they say:Trade is just like usury; whereas Allah permitteth trading and forbiddeth usury. He unto whom an admonition from his Lord cometh, and (he) refraineth (in obedience thereto), he shall keep (the profits of) that which is past, and his affair (henceforth) is with Allah. As for him who returneth (to usury) - such are rightful owners of the Fire. They will abide therein". See, Mohammed Pickthall, Op.cit, p. 59. Habib Adjie dan M.Hafidh, 2014, Akta Perbankan Syariah yang Selaras Pasal 38 UUJN-P, Pustaka Zaman, Semarang, pp. 59-62.
} 
Departure from the two above surahs, according to Faturrahman Djamil, any form of cashless trading must be set down in a writing agreement. The logical basic is a writing agreement can be an evindence if there would emerge a dispute at a later day because one party is assumed by the other one that he has been done the breach of contract or a violation of an obligation through carelessness (negligence) or intentional wrong doing in fraud. ${ }^{32}$ Then, what I mean by fairness or impartiality on the agreement of two parties is a notary whose authorization shall advice or remind the parties to comply the Sharia principle, and by the some token the Akad of the Islamic banking performed by the cashless payment must be made in writing because it is the most important part that should be done therein. The role of notary, therefore, is needed to give legal opinions to the parties in the Akad making which should not be contrary to the
Islamic law and applicable laws in Indonesia.

\section{Conclusion}

A dispute potential in Sharia economic transaction can take place if one party violates the contract by carelessness (negligence) or intentional wrong doing to the other party. In practice, the Islamic banks do not apply the Sharia principle, however, it is clearly noted in the bookkeeping. They also do infringes to the prudential principle because the system is still running not perfect. The urgency of notarial deed is an deed having a powerful evindence in a dispute, becoming a binding agreement, securing the respective rights and obligations of the respective parties. The making of an authentic deed is performed by the parties in the framework of creating legal certainty, legal order and legal protection.

\section{REFERENCES}

\section{A. Books}

Adjie, Habib dan M.Hafidh, 2014, Akta Perbankan Syariah yang Selaras Pasal 38 UUJN-P, Edisi Revisi, Pustaka Zaman, Semarang. Akgunduz, Ahmed, 2010, Introduction to Islamic

Law Islamic Law in Theory and Practice, Islamitische University Press (IUR), Rotterdam.

Ali, Zainuddin 2009, Hukum Ekonomi Syariah, Sinar Grafika, Jakarta.

Djamil, Fathurrahman, 2013, Hukum Ekonomi Islam: Sejarah, Teori dan Konsep, Editor Tarmizi, Sinar Grafika, Jakarta. ,2012, Penerapan Hukum Perjanjian dalam Transaksi di Lembaga Keuangan Syariah, Sinar Grafika, Jakarta.

Hernoko, Agus Yudha 2010, Hukum Perjanjian, Asas Proporsionalitas dalam Kontrak Komersial, Kencana Prenada Media Group,
Jakarta.

Lindsey, Tim, et al., 2013, Hukum Keluarga, Pidana \& Bisnis Kajian Perundang-undangan Indonesia Fikih dan Hukum Internasional, Kemcana Prenada Media Group, Jakarta.

Mardani, 2014, Hukum Bisnis Syariah, Kencana Prenata Media Group, Jakarta.

Marzuki, Peter Mahmud, 2011, An Introduction to Indonesian Law, Setara Press, Malang.

Pickthall, Marmaduke, 1938, The Meaning of Glorius Koran, Government Central Press, Hyderabad-Deccan.

Poerwadarminta, W.J.S., 2003, Kamus Umum Bahasa Indonesia, Balai Pustaka, Jakarta.

Subekti, 1975, Pokok-pokok dari Hukum Perdata, Intermasa, Jakarta.

Suharnoko, 2014, Hukum Perjanjian Teori dan Analisa Kasus, Kencana Prenada Media Group, Jakarta. 
Sutedi, Adrian, 2009, Perbankan Syariah Tinjauan dari Beberapa Segi Hukum, Ghalia Indonesia, Bogor.

Winata, Frans Hendra, 2011, Hukum Penyelesaian Sengketa Arbitrase Nasional \& Internasional, Sinar Grafika, Jakarta.

\section{B. Journal Article}

Yulianti, Rahmani Timorita, "Asas-Asas Perjanjian (Akad) dalam Hukum Kontrak Syari'ah", Jurnal Ekonomi Islam, Vol. II, No.1, Juli 2008.

\section{Anthology}

Abd. Shomad, "Rekonstruksi Akad Bank Syariah untuk Mencapai Kemaslahatan sebagai Wujud Rahmatan Lil-Alamin", in M.Isnaeni, 2013, Perkembangan Hukum Perdata di Indonesia, Laksbang Grafika, Surabaya.

Trisadini Prasatinah Usanti, "Urgensi Jaminan pada Pembiayaan Berdasarkan Prinsip Bagi Hasil di Bank Syariah" in M. Isnaeni, 2013, Perkembangan Hukum Perdata di Indonesia, Laksbang Grafika, Surabaya.

\section{Internet}

Sukardi, Budi, "Kepatuhan Syariah (Syariah Z Compliance) dan Inovasi Produk Bank Syariah di Indonesia", http://stainmetro. ac.id/e-journal/index.php/akademika/article/ download/61/55, accessed on November 18, 2015.

\section{E. Laws and Regulation}

Law Number 21 of 2008 Concerning Sharia (Islamic) Banking (State Gazette of the Republic of Indonesia Year 2008 Number 94, Supplement to State Gazette of the Republic of Indonesia Number 4867). 